From the Third Medical Clinic of Kyoto University (Director: Professor M. Maekawa, $M$. D.)

\title{
Studies on the Experimental Myocarditis and Bacillemia by \\ Tubercle Bacillus (II)
}

\section{Experimental Myocarditis by Tubercle Bacilli with Rabbit-Myocardium-Phosphatide (2)}

$\mathrm{BY}$

SHUKICHI TAKAGI

(Received for Publication May. 35, 1950)

\section{結核困に依る心筋炎並びに菌血症に關する實驗的硎究（第 2 報）}

第一編 家鬼心筋フォスファティード加結核菌に依る實驗的心筋炎（2）

$$
\text { 醫學士 高 木 脩 吉 }
$$

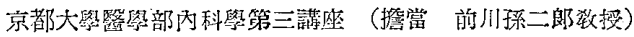

\section{Clinical Result}

Not so remarkable changes were confirmed in body weight, temperature, blood pressure, respiration, puls rate, heart sound, blood picture and roentgenogram.

Urobilinogen and urobilin reactions in urine were temporarily positive after frequent sensitizations, but the former showed no difference

$$
\begin{gathered}
\text { 第三章 實 噞 成 績 (1) } \\
\text { 第一節 臨 床 所 㫕 }
\end{gathered}
$$

家需心筋フォスファティード加結核人型 $\mathrm{F}$ 株纯菌を以

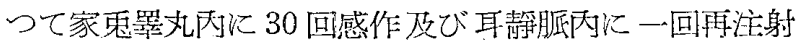
を行い，其の全經過中之を臨床的に觀察して，得たる所 見は下記の如くで岕つた。

1）體重 比較的幼若家霓を用いた結果，本試驗在び 對照家秋霖共に，初感染より第13.回感作に至る期間は 成長に因る體重增加は抑制され，以後稍々增加倾向を認 めたが常に充分とは言い䧼く，第 20 回感作以捘は著變 学認めなからた。（第一表）

2）體溫 著變を認めず（第一表）

3）血警 本試驗及び對照試驗家鬼群共に正常範園内 の動搂に留つた．本試驗家束 No. 301，302，對招試驗家 鬼 No. 305 は䘞期に動摇稍々甚だしかつたが，俔性に 因るるのと思惟された。(第一表)

4) 呼吸數 實驗に因る變動を認めず. 10 [回測定 1 分 間平均值を記する。

本試驗啫: No. 301, 54 ; No. 302, 53 ; No. 303, 46.

對照試驗群 : No. 304, 40; No. 305, 52 ; No. 305, 60. 總平均一分間值 : 51 .

5）心音死び心搏動數 全實驗動物儿就き全實驗經過 中純音を聽取した，心搏動數は各家躳の前後 10 回沉亘 万測定 1 分間值は何れも 160 乃至 220 の間を動摇し，概 compared with the control.

Ecg. in the most of all rabbits showed generally low voltage, but CPR. (Cor-Phosphatid-Reaction) in the cases was continuously positive. These facts suggest some myocardial damage.

Tuberculin test on all animals showed a pretty high tuberculin-allergy.

ね正常搏動數の閾內にあつた。

6) 尿所見 聂：導尿に依つて得た供試膀胱尿は 20 乃至 30cc.で岕つた。

外觀夷び比重：外觀は全實驗家鬼の前後 10 回の检尿 に於て，其の時期に依り黄褐色乃至亲黄色，透明尿より 濃白濁へと種々の色調立びに溷濁度を呈した。比重も $15^{\circ} \mathrm{C}$ で最低 1013 より最高 1039 の間を動播した。各動 物の 10 回測定平均值は，本試驗家兔：No. 301，1027； No. 302；1025；No. 303, 1026 ; 對照試驗家鬼：No. 304,1029 ; No. 305, 1025 ; No. 306, 1025 ; 總本均值 :

Table 1.

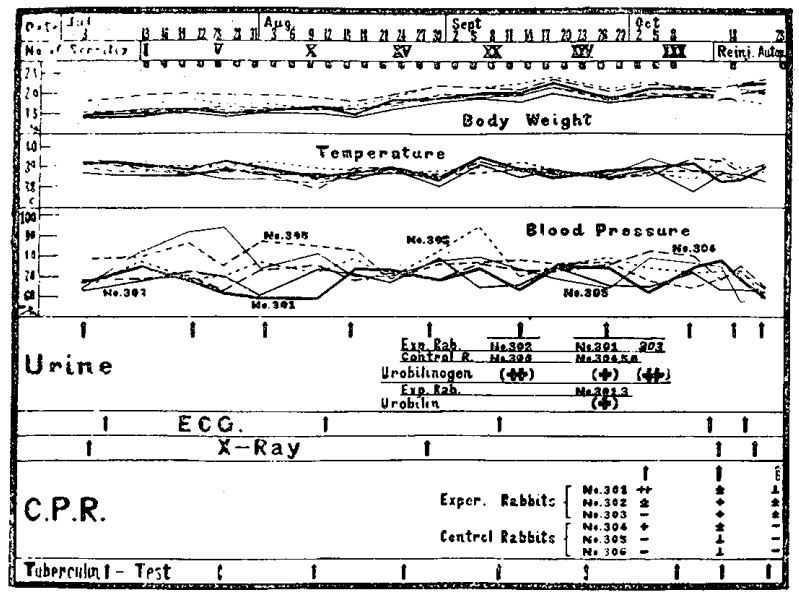


Table 2 .

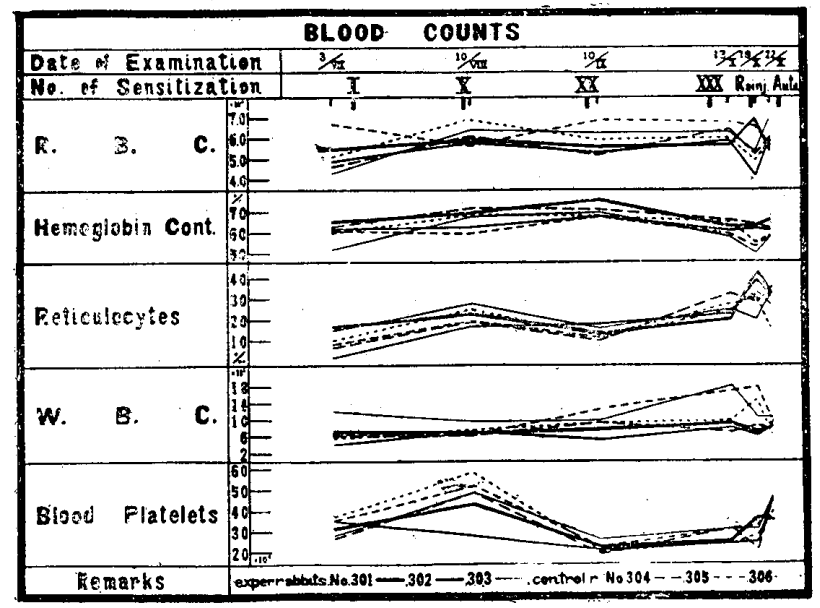

Table 3.
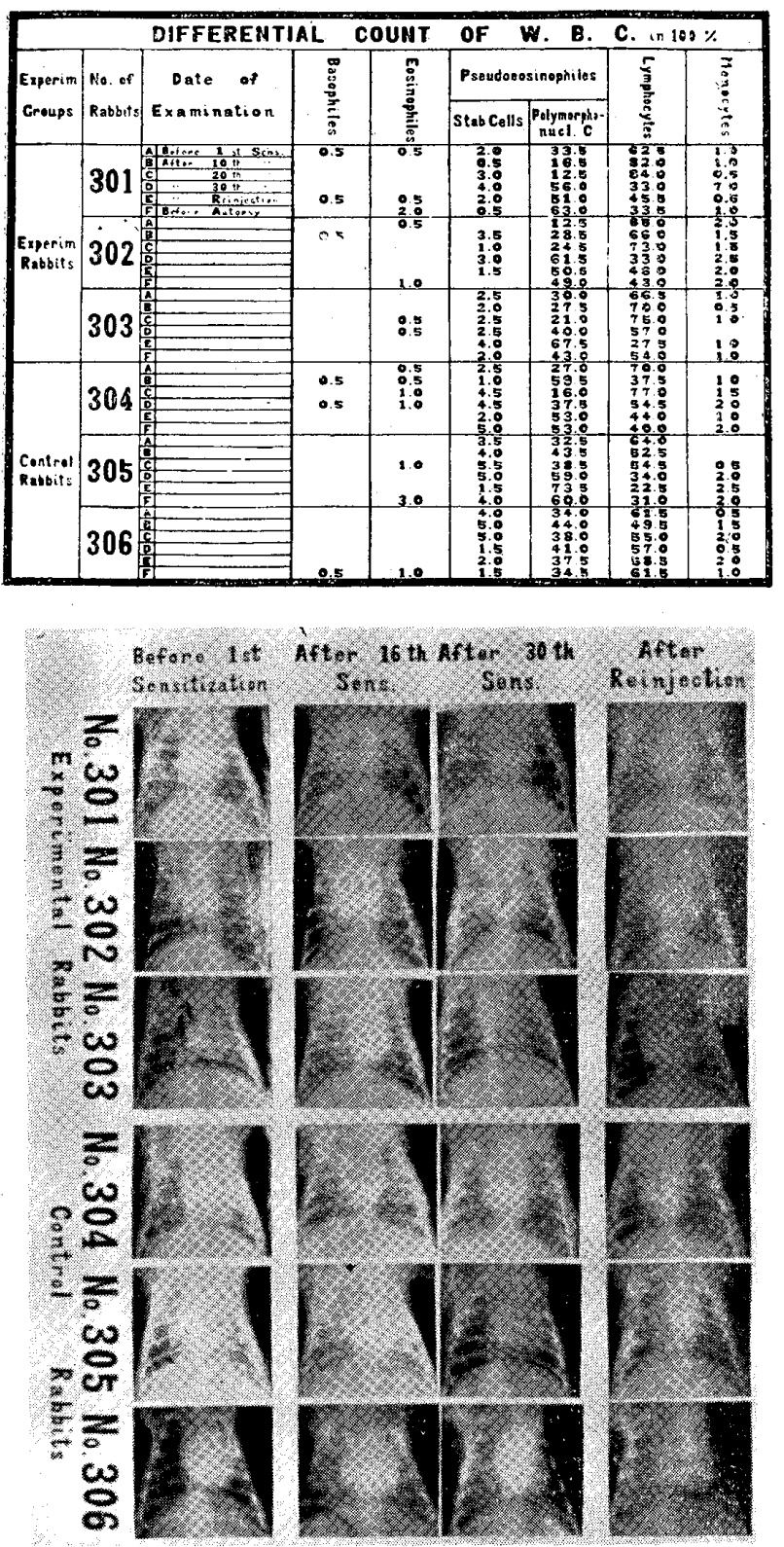

Photo. 1.
1026 であつた。唒外觀の肉眼的润濁度と比重の輕重ば， 必ずしも本行しなかつた。何れも食餌の影響と見られ實 驗に因する戀動と見做し得なかつた。

反雔: 全實驗家香の總ての測定期にアルカリ性反應を 示した。

蛋白，糖及びビリルビン反㕍：全經過中全實驗動物に 於て各反應共に陰性であつた。

ウロビリノーゲン，ウロビリン反應：本試驗家鬼 No. 301 は第 26 回感作後兩反應弱昜性，No. 302 は第 21 回 感作挠ウロビリノーゲン反㷳陽性，No. 303 は第 26 [回] 感作後ウロビリノーゲン反㷳陽性, ウロビリン反應弱昜 性を示し，對照試驗家鬼 No. 304, 305 は第 26 回感作後 ウロビリノーゲン反應弱昜性，No. 306 は第 21.26 回感 作後ウロビリノーゲン反應夫々陽性，弱陽性を示した。 即ち何れも一過性で，其の前啳の檢尿に於いては陰性に

Table 4.

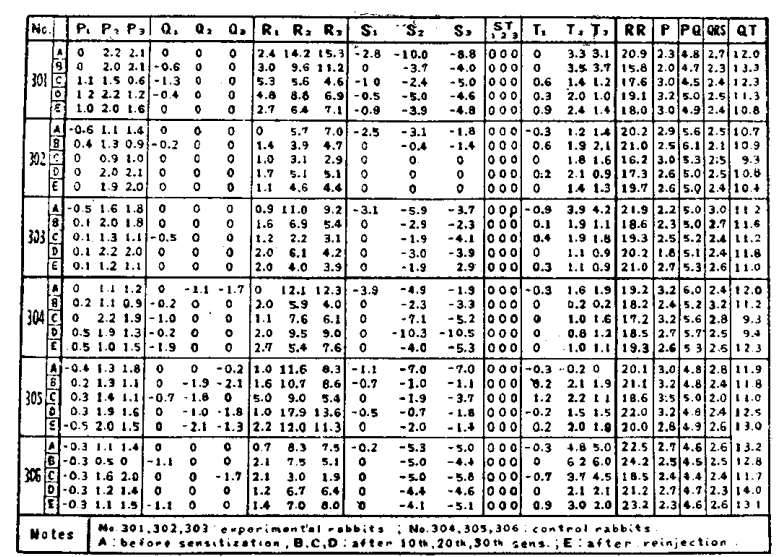

Table 5 .

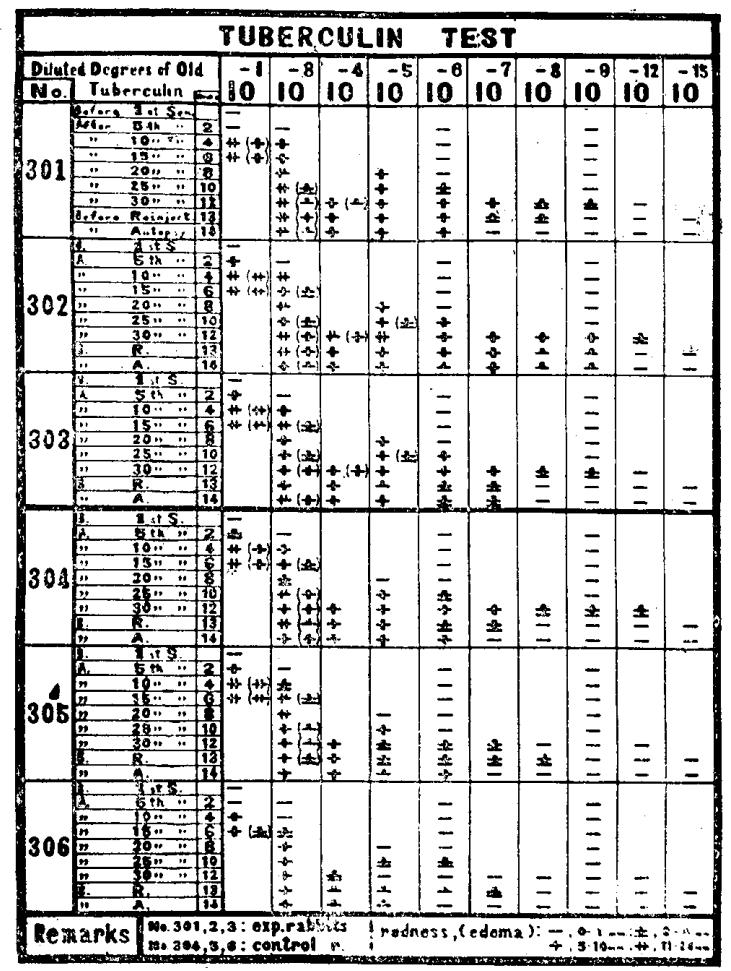

JAPANESE CIRCULATION JOURNAI. 
終始し，且つ本試驗群と辈照試驗群との閒にも本質的な 差岩認めなかつた(第一表)。

沈渣：全經過中各家鬼つ沈渣に無機監類て認めた以外 に，細胞性要素及び圓鑄等の病的所見を認めなからた。

7）血液所胃 第二表江示寸如く赤血球數友び血色素 含有量に著變を認めず，白血球數は稍々增加傾向を示す 家秋が本試驗及び對照試驗群共に安つたが，其の分類上

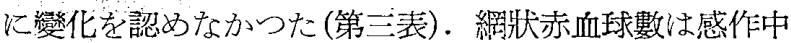
一時潧加傾向を見せ，再注射の前後に於ても增加傾向学 見た．又血小板數は感作初期に可成り上昇し，後期に却 つて減少し，再注射後再び增加した．併し共に本試驗群 と對照群の間に著害を認めなからた。

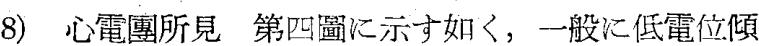

向を示した。

9）X線所見 全實驗家鬼に於て著變を認めず。本實 驗に依つて得た肺の組織學的變化はX線像に於て證明杢 能であつた。(寫顀一)

10）CPR. 第一表に示す如くであつた．再注射後の 所見を後述の組織學的所見そ對比すれば，心筋炎を良く 檢出し得たものと言えよう。

11）・ベルクリン反應所見今村220)の判定標準に依 り表示すれば第五表に示した如くであつた。稀釋度の高 度となるに從い不定的となり，10-3 以上の稀釋度に於て は評價に不難を感ずる。

交献 第五報末尾に一括記載する。

From the Third Medical Clinic of Kyoto University (Director: Professor M. Maekawa, M. D.)

\section{Studies on the Experimental Myocarditis by the \\ Lung-Phosphatide (II)}

$\mathrm{BY}$

SHVKICHI TAKA(:I

(Received for Publication, May. 25, 195j)

\section{肺臟フォスファティード加牛血清に依る實驗的心筋炎に關する硏究（第 2 報） \\ 㗨學上高木 脩 吉

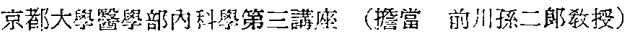

In the clinical observations, body weight, temperature, respiration, puls rate, cardiac sound, blood pressure, blood picture and roentgenogram showed no remarkable changes.

Protein reaction in urine was temporarily positive after the reinjection.

Urobilinogen and urobilin reactions in urine were temporarily or continuously positive after the reinjection.

Ecg. showed generally low voltage and especial-

\section{第三章 實 驗 成 績 (I)

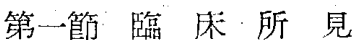

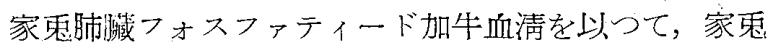
耳靜胍內に感作支び再注射を行い，得た䧑床所見は下記 の如くでめつた。

本試驗家鬼 No. 161，162，163 は第 1 回再注射啳ショ

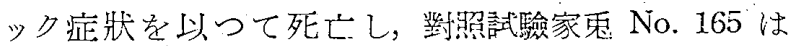
Arthus 現象施行後下㰣症狀马以つて死亡した。

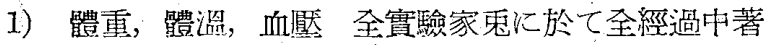
明な變動を見ず，對照試驗と本試驗の間厄も差異を認め なかっった(第一表)。

2）呼吸數 全經過中正常值範園內にあり，實驗に区 ly low or reverse $\mathbf{T}$, which suggested myocardial damage.

Serologically, PPR. (Pulmonum-Phosphatid-Reaction) before and after the reinjection were positive.

ARTHUS's phenomena by a mixture of oxen sera and rabbit-lung-phosphatide and by the former alone were positive, but by the latter alone negative.

する變動を諗めなかつた．各家鬼の4万至 7 回に亘る測 定値の平均 1 分間值を記載する。

本試驗：No. $321: 48$, No. $322: 72$, No. 323: 42, No. $324: 40$, No. $161: 73$, No. 162: 54, No. 163: 66 . 對照試驗 : No. $325: 64$, No. $164: 69$, No. $165: 54$. 全家躳平均 1 分間値 : 58 .

3）心音及び心搏動數 全經過中全例に於て純音を聽 取した。 心搏動數は各家鬼各測定 1 分閒值は 140 万至 240 の間を動摇し大體正常範囯內の值を示した。

4) 尿所見 量：導尿法によつて得た膀胱尿は 12 乃 至 32cc. であり，之を供試した。

外觀：各實驗家乘の各檢査赫期により，黃褐色透明尿 